\title{
Pengaruh Pemberian Ekstrak Daun Teh Hijau (Camellia Sinensis) Terhadap Penurunan Berat Badan Pada Tikus Putih (Rattus Novergicus L.) Jantan Galur Wistar Yang Diberi Diet Tinggi Lemak
}

\author{
Ainul Mardiyah Rahmah Zalukhu1, Debby Mirani Lubis ${ }^{2}$ \\ ${ }^{1}$ Fakultas Kedokteran Universitas Muhammadiyah Sumatera Utara \\ ${ }^{2}$ Bagian Fisiologi, Fakultas Kedokteran, Universitas Muhammadiyah Sumatera Utara
}

email: Ainul.rahmah98@gmail.com

\begin{abstract}
ABSTRAK
Obesitas disebabkan karena asupan energi yang digunakan berlebih dibandingkan dengan penggunaan semestinya yang akan menimbulkan adanya timbunan triasilgliserol yang berlebih pada jaringan lemak. Setiap tahunnya terjadi peningkatan angka kejadian obesitas penduduk Indonesia. Penanganan overweight dan obesitas salah satunya dengan teh hijau (Camellia sinensis). Kandungan utama teh hijau adalah polifenol katekin. Katekin pada teh hijau dapat membantu melancarkan proses pencernaan makanan. Hal ini terjadi melalui stimulasi peristaltik dan produksi cairan pada saluran pencernaan. selain itu, juga dapat mempengaruhi metabolisme tubuh dan membantu proses penurunan berat badan. Metode penelitian yang digunakan dalam penelitian ini menggunakan rancangan penelitian eksperimental dengan desain pre dan post test group design. Penelitian ini menunjukkan teh hijau mampu menurunkan berat badan dengan nilai $p=0.000(<0,05)$. Pada penelitian ini dapat disimpulkan bahwa terdapat penurunan berat badan dengan pemberian teh hijau.

Kata kunci: Katekin, kelebihan berat badan, obesitas, penurunan berat badan, teh hijau.
\end{abstract}

(cc) EY This work is licensed under a Creative Commons Attribution 3.0 License.

\section{PENDAHULUAN}

Obesitas merupakan suatu keadaan terjadinya akumulasi lemak yang berlebihan dijaringan lemak tubuh (adiposa). ${ }^{1} \quad$ Setiap tahunnya terjadi peningkatan angka kejadian obesitas penduduk Indonesia. Mengutip dari Riskesdas tahun 2018, prevalensi berat badan lebih dan obesitas pada dewasa $>18$ tahun pada tahun 2013 sampai 2018 sangat signifikan. Pada tahun 2013, prevalensi berat badan lebih yaitu 11,5\% dan pada tahun 2018 meningkat sebesar $13,6 \%$. prevalensi obesitas pada tahun 2013 yaitu $14,8 \%$ dan pada tahun 2018 terjadi peningkatan menjadi $21.8 \%$. Hasil riset di 35 provinsi pada tahun 2018 menurut kementrian kesehatan RI menyatakan bahwa provinsi Sumatera Utara berada di peringkat ke-7 yaitu $25 \%{ }^{2}$ Sepertiga dari penduduk di beberapa negara industri mengalami kegemukan dan biasanya juga kegemukan sangat erat kaitannya dengan terjadinya penyakit kronik yang dapat menjadi penyebab pembunuh utama di negara-negara tersebut. Obesitas bukan hanya tentang kosmetik, tetapi telah menjadi masalah kesehatan yang harus lebih diperhatikan, karena sering disertai dengan berbagai penyakit dan bisa 
menjadi komplikasi suatu penyakit seperti diabetes melitus (DM) tipe 2, hipertensi, dislipidemia, gangguan pernafasan, kanker, dan lain-lain. $^{3}$

Penanganan terhadap overweight dan obesitas telah diteliti dan dilaksanakan. Penanganan ini antara lain melalui perubahan gaya hidup, aktivitas fisik, pengaturan pola makan (diet), obatanobatan, operasi, dan pengobatan alternatif dengan cara tradisional antara lain melalui pengobatan herbal. Saat ini pengobatan secara herbal lebih banyak diminati masyarakat karena biayanya relatif murah. Pengobatan herbal ini juga sudah digunakan untuk penanganan overweight dan obesitas, salah satunya adalah dengan pemilihan teh hijau (Camellia sinensis) mampu menurunkan berat badan dan kadar lemak. Tradisi minum teh telah menjadi kebiasaan masyarakat dan teh dikenal luas, teh hijau (Camellia sinensis) relatif murah dan mudah didapatkan serta teh hijau (Camellia sinensis) merupakan teh yang paling alami dan belum mengalami proses perubahan. ${ }^{4}$

Proses pembentukan teh hijau (Camellia sinensis) dilakukan dengan cara menginaktifasi enzim oksidase atau fenolase yang terdapat pada pucuk daun teh segar, yaitu melalui proses pemanasan ataupun penguapan dengan menggunakan uap panas yang bertujuan agar mencegah terjadinya oksidasi enzimatik terhadap katekin dalam daun teh. Teh hijau (Camellia sinensis) merupakan tumbuhan obat yang mempunyai efek farmakologis antara lain dapat menurunkan berat badan, menurunkan kolesterol, trigliserida, serta glukosa, dapat mencegah karies pada gigi, antimutagenik, antioksidan, dan antibakteri. $^{3}$

\section{METODE PENELITIAN}

Metode penelitian yang digunakan dalam penelitian ini menggunakan rancangan penelitian eksperimen dengan desain pre dan post test group design dengan menggunakan hewan coba tikus putih (galur wistar) dibagi menjadi 2 kelompok yaitu satu kelompok kontrol positif $(\mathrm{K}+)$, satu kelompok perlakuan (P1). Penelitian ini dilaksanakan di Unit Pengelolaan Hewan Laboratorium (UPHL) Fakultas Kedokteran Universitas Muhammadiyah Sumatera Utara .

Populasi penelitian ini adalah hewan percobaan tikus (Rattus norvegicus.L) jantan yang diperoleh dari Unit Pengelolaan Hewan Laboratorium (UPHL) Fakultas Kedokteran Universitas Muhammadiyah Sumatera Utara. Populasi yang memenuhi kriteria yang akan digunakan sebagai sampel atau populasi studi. Dalam menetapkan jumlah Sampel penelitian yang digunakan menggunakan rumus Federer. Jadi seluruh sampel yang digunakan sebanyak 32 ekor yang dibagi dalam 2 kelompok, setiap kelompok terdiri dari 16 tikus perlakuan dan 16 tikus kontrol, Kemudian ditambahkan masingmasing kelompok 2 tikus cadangan apabila dalam penelitian tikus tiba-tiba mati saat percobaan dilakukan, maka dibutuhkan tikus tambahan.

Kriteria Inklusi

1. Tikus dalam keadaan sehat

2. Tikus tidak memiliki kelainan anatomis

3. Tikus berumur 8-12 minggu

4. Berat badan melebihi berat badan normal tikus (>200 gram)

Kriteria Eksklusi (Drop out)

1. Tikus dengan berat badan kurang

2. Tikus yang tidak mau makan dan tikus yang mengalami penurunan keadaan fisik atau mati. 
Penelitian ini dilakukan di Fakultas Kedokteran Universitas Muhammadiyah Sumatera Utara. Sampel yang digunakan adalah tikus putih (Rattus Novergicus L.) jantan galur wistar sebanyak 32 ekor terhadap 2 kelompok, yaitu kelompok kontrol dan kelompok perlakuan. Penelitian ini telah disetujui oleh Komisi Etik Penelitian Kesehatan Fakultas Kedokteran Universitas Muhammadiyah Sumatera Utara dengan No.325/KEPK/FKUMSU 2019.

\section{HASIL PENELITIAN}

Penelitian kandungan teh hijau dilakukan di Fakultas MIPA Laboratorium Kimia Bahan Alam Hayati Universitas Sumatera Utara. Sampel yang digunakan adalah daun teh hijau dari Sidamanik. Tetapi saat penelitian, Pemeriksaan kandungan teh dibatasi dengan alat yang terbatas, Sehingga kandungan teh yang spesifik untuk menurunkan berat badan tidak dapat dinilai.

Tabel 1. Skrining Kandungan Teh Hijau

\begin{tabular}{|c|c|c|c|}
\hline No & $\begin{array}{c}\text { SENYAWA METABOLIT } \\
\text { SEKUNDER }\end{array}$ & PEREAKSI & $\begin{array}{c}\text { HASIL } \\
\text { SKRINING }\end{array}$ \\
\hline 1 & FLAVONOID & $\mathrm{FeCl}_{3} 5 \%$ & + \\
\hline & & $\mathrm{NaOH} 10 \% \%$ & - \\
\hline & & $\mathrm{H}_{2} \mathrm{SO}_{4(\mathrm{p})}$ & - \\
\hline 2 & ALKALOID & Bouchardart & - \\
\hline & & Dragendroff & - \\
\hline 3 & TERPENOID & Salkowsky & - \\
\hline & & $\mathrm{CeSO}_{4} 1 \%$ dalam $\mathrm{H}_{2} \mathrm{SO}_{4} 10 \%$ & + \\
\hline 4 & STEROID & Salkowsky & - \\
\hline & & $\mathrm{CeSO}_{4} 1 \%$ dalam $\mathrm{H}_{2} \mathrm{SO}_{4} 10 \%$ & - \\
\hline 5 & TANIN & $\mathrm{FeCl}_{3} 5 \%$ & + \\
\hline 6 & SAPONIN & Aquadest+alkohol $96 \%+\mathrm{HCL} 2 \mathrm{~N}$ & + \\
\hline
\end{tabular}

Dari hasil kandungan teh hijau di atas, tidak didapatkan adanya EGCG, LTheanine maupun caffein di dalam skrining teh hijau dikarenakan terbatasnya alat yang digunakan. Tetapi pada skrining di atas didapatkan Flavonoid positif, di mana flavonoid dapat menghambat peroksidasi lipid dan proses lipooksigenasi in vitro. ${ }^{5}$

Pada flavonoid juga terdapat katekin. Katekol pada flavonoid teh adalah sebagai penyusun utama yang biasa disebut dengan katekin. Katekin sendiri disintesa melalui lintasan phenyl-propanoid dan flavonoid. ${ }^{6}$

Selanjutnya dilihat dari tabel di atas, Tanin juga terdapat di dalam teh. Tanin berpengaruh terhadap sifat 'astrigency' dan adanya rasa pahit. Tanin yang terdapat di dalam teh terdiri dari katekin seperti epicatechin (EC), epigallocatechin (EGC), epicatechin gallate (ECG), dan epigallocatechin gallate (EGCG). ${ }^{6}$

Saponin juga terlihat positif terdapat di dalam teh. Saponin pada teh memiliki aktivitas biologis diantaranya saponin bersifat hemolisis, anti inflamasi, antibakteri, antimikroba, toksik terhadap ikan, analgesik, insektisida, dapat menghambat penyerapan alkohol, dan lain-lain. ${ }^{6}$

Tabel 2 Berat Badan Tikus (Kelompok Perlakuan)

\begin{tabular}{ccc}
\hline \multirow{2}{*}{$\begin{array}{c}\text { Sampel } \\
\text { (Perlakuan) }\end{array}$} & \multicolumn{2}{c}{ Berat Badan $(\mathbf{g})$} \\
\cline { 2 - 3 } & Sebelum & Sesudah \\
\hline 1 & 209.32 & 158.14 \\
2 & 217.76 & 160.22 \\
3 & 210.25 & 162.26 \\
4 & 215.35 & 150.73 \\
5 & 202.15 & 149.76 \\
6 & 211.26 & 164.98 \\
7 & 214.11 & 170.43 \\
8 & 212.93 & 165.23 \\
9 & 214.22 & 168.55 \\
10 & 215.56 & 159.34 \\
11 & 216.42 & 171.24 \\
12 & 212.52 & 167.85 \\
13 & 215.15 & 166.66 \\
14 & 212.44 & 161.77 \\
15 & 211.17 & 159.79 \\
16 & 212.89 & 171.22 \\
\hline Rerata & 212.72 & 163.02 \\
SD & 3.63568 & 6.58403 \\
\hline
\end{tabular}

Pada tabel 2 didapati bahwa berat badan tikus putih (Rattus Novergicus L.) jantan galur wistar pada kelompok perlakuan menunjukkan bahwa sebelum diberikan pakan biasa dan pemberian 
ekstrak teh hijau (Camellia Sinensis) ratarata berat badan tikus putih jantan galur wistar adalah 212.72 $\pm 3.63568 \mathrm{~kg}$. Sesudah diberikan pakan biasa dan pemberian ekstrak teh hijau (Camellia Sinensis), rata-rata berat badan tikus putih jantan galur wistar adalah $163.02 \pm 6.58403$.

Pada tabel 3 didapati bahwa berat badan tikus putih (Rattus Novergicus L.) jantan galur wistar pada kelompok kontrol menunjukkan bahwa badan tikus putih jantan galur wistar adalah $206.75 \pm 4.29729$ kg. Sesudah diberikan pakan biasa dan pada kelompok kontrol tidak diberikan ekstrak teh hijau (Camellia Sinensis), ratarata berat badan tikus putih jantan galur wistar adalah $218.55 \pm 5.82935 \mathrm{~kg}$.

Tabel 3. Berat Badan Tikus (Kelompok Kontrol)

\begin{tabular}{ccc}
\hline \multirow{2}{*}{$\begin{array}{c}\text { Sampel } \\
\text { (kontrol } \\
\text { negatif) }\end{array}$} & $\begin{array}{c}\text { Awal } \\
\text { (Minggu ke- }\end{array}$ & $\begin{array}{c}\text { Akhir } \\
\text { (Minggu ke-4) }\end{array}$ \\
\hline 1 & 208.00 & 213.11 \\
2 & 202.00 & 212.16 \\
3 & 202.00 & 213.23 \\
4 & 208.00 & 217.24 \\
5 & 216.00 & 220.12 \\
6 & 205.00 & 215.86 \\
7 & 208.00 & 219.30 \\
8 & 205.00 & 219.78 \\
9 & 207.00 & 227.76 \\
10 & 215.00 & 217.86 \\
11 & 206.00 & 213.68 \\
12 & 208.00 & 229.86 \\
13 & 204.00 & 219.25 \\
14 & 201.00 & 227.36 \\
15 & 210.00 & 220.54 \\
16 & 203.00 & 209.69 \\
\hline Rerata & 206.75 & 218.55 \\
SD & 4.29729 & 5.82935 \\
\hline
\end{tabular}

Berdasarkan tabel 4 yang telah dilakukan uji normalitas menggunakan SPSS, didapatkan data yang menunjukkan bahwa kelompok perlakuan dan kontrol pada variabel Berat Badan
Awal dan Berat Badan Minggu Keempat semuanya menunjukkan nilai yang signifikan. Uji yang dipertimbangkan pada penelitian ini adalah Uji Shapiro-Wilk, karena data hanya berjumlah 32 di mana kurang dari 50. Nilai signifikansi ( $p$ ) pada Uji Shapiro-Wilk adalah nilai yang melebihi standar margin tertentu ( $p>0.05)$, sehingga berdasarkan uji normalitas shapiro-wilk data berdistribusi normal.

Tabel 4. Uji Normalitas

\begin{tabular}{ll}
\hline \multicolumn{1}{c}{ Variabel } & $\mathrm{p}$ value \\
\hline $\begin{array}{l}\text { Berat badan sebelum } \\
\text { kelompok perlakuan }\end{array}$ & 0,581 \\
$\begin{array}{l}\text { Berat badan sesudah } \\
\text { kelompok perlakuan }\end{array}$ & 0,224 \\
$\begin{array}{l}\text { Berat badan sebelum } \\
\text { kelompok kontrol }\end{array}$ & 0,144 \\
$\begin{array}{l}\text { Berat badan sesudah } \\
\text { kelompok kontrol }\end{array}$ & 0,278 \\
\hline
\end{tabular}

Berdasarkan gambar 1 terlihat adanya perbandingan terhadap masingmasing kelompok. Kelompok yang diberi ekstrak teh hijau terlihat adanya pengaruh terhadap penurunan berat badan dibandingkan kelompok yang tidak diberi ekstrak daun teh hijau.

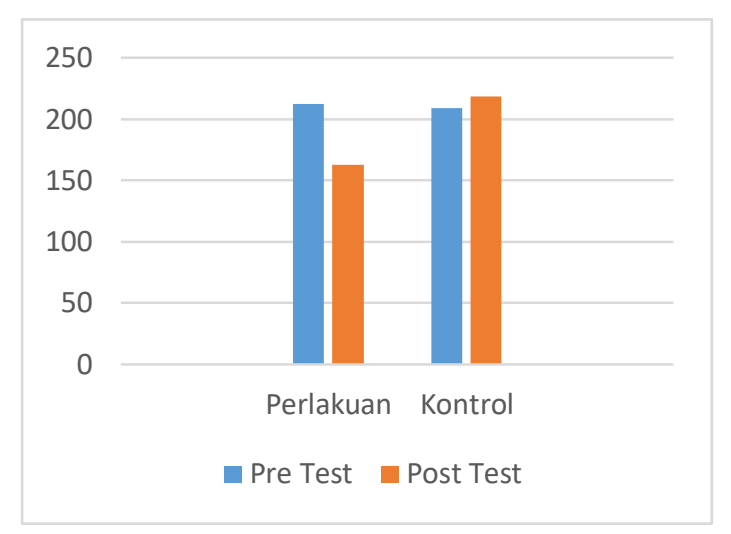

Gambar 1. Rata-rata Berat Badan pada kelompok kontrol dan perlakuan 
Data pada penelitian ini berdistribusi normal karena uji normalitas data mendapatkan hasil $p$-value $>0.05$. kemudian pengujian statistik dilanjutkan dengan menggunakan Uji T Berpasangan untuk membandingkan perbedaan ratarata berat badan.

Berdasarkan tabel 5 dan 6 yang telah dilakukan dengan Uji Paired Sample $T$ Test pada kedua kelompok kontrol dan perlakuan dengan menggunakan SPSS, didapatkan data yang menunjukkan nilai sig. Sebesar 0,000 ( $p$-value < 0.05). Hal ini menunjukkan bahwa terdapat nilai yang signifikan terhadap kedua kelompok yang dilakukan Uji Paired Sample T Test.

Tabel 5. Uji T Berpasangan (Paired T Test) Perlakuan

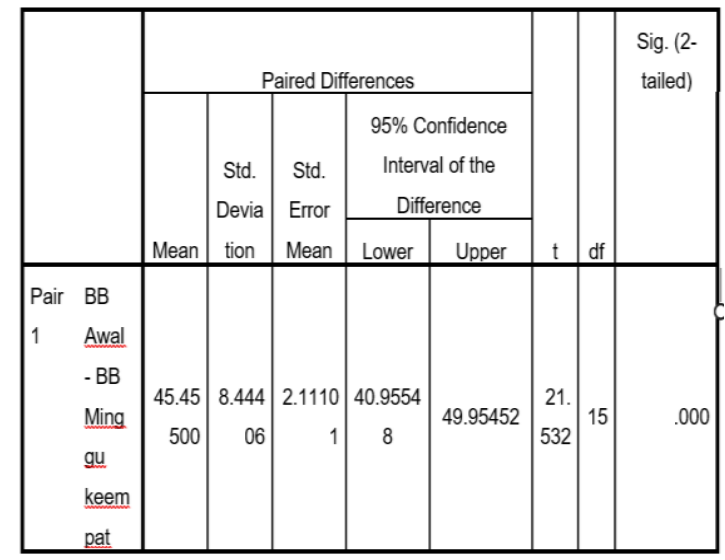

Tabel 6. Uji T Berpasangan (Paired T Test) Kontrol

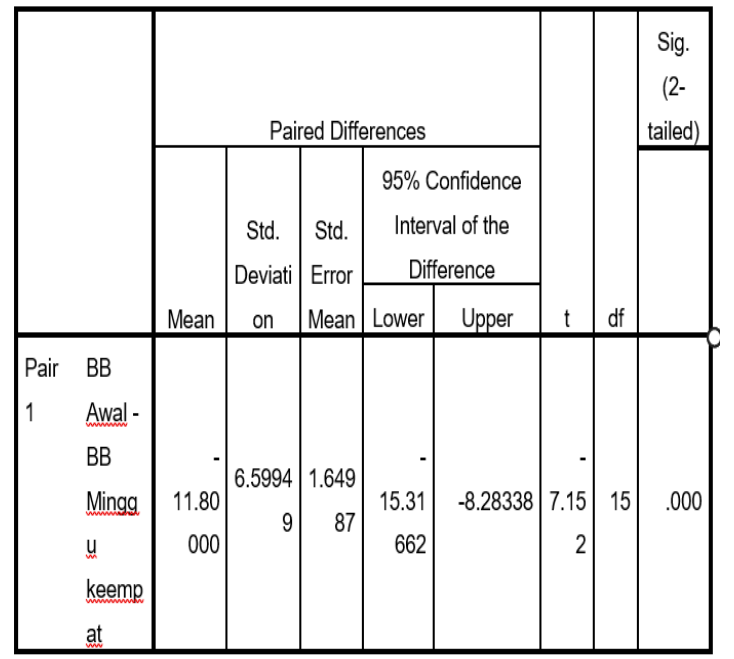

\section{PEMBAHASAN}

Berdasarkan hasil penelitian yang dilakukan pada masing-masing kelompok dengan menggunakan spps, menunjukkan bahwa terdapat pengaruh pemberian ekstrak daun teh hijau (Camellia Sinensis) terhadap penurunan berat badan pada tikus putih (Rattus novergicus L.) jantan galur wistar. Hasil penelitian ini sejalan dengan penelitian sebelumnya oleh Kartika Dewi yang mengatakan bahwa pemberian ekstrak daun teh hijau pada tikus terbukti dapat menurunkan berat badan dan kadar trigliserida tikus. ${ }^{3}$

Kelebihan kalori, terutama disimpan dalam bantalan lemak, menyebabkan deregulasi sistemik seperti dislipidemia, resistensi insulin, diabetes mellitus tipe 2 (T2DM), penyakit ganas, aterosklerosis dan komplikasi jantung lainnya. ${ }^{7,8} \mathrm{Hal}$ ini sesuai dengan penelitian Aulia yang mengatakan bahwa Komplikasi dari obesitas dapat mengenai beberapa organ tubuh antara lain saluran pernapasan, otak, jantung, paru-paru, ginjal, dan kulit. ${ }^{9}$

Pencegahan dan pengobatan obesitas yang efektif dikenal sebagai terapi perilaku berbasis diet dan latihan fisik dan / atau dalam kombinasi terapi farmakologis, namun, sulit bagi kebanyakan orang karena gaya hidup mereka. Meskipun banyak agen farmakologis saat ini tersedia untuk pengobatan obesitas tetapi dengan kemanjuran terbatas dan efek samping yang bersangkutan. Dengan demikian, penelitian dalam identifikasi produk alami dari diet dan herbal dengan sifat antiobesitas semakin populer akhir-akhir ini. ${ }^{10}$

Teh berbasis Camellia adalah salah satu minuman yang paling banyak dikonsumsi di dunia. Popularitas mereka sebagian karena fakta bahwa mereka mengandung sejumlah besar kafein alkaloid purin dan sejumlah theobromine. ${ }^{11}$ Pada 2010, 3,2 juta metrik ton teh kering diproduksi, $61 \%$ di 
antaranya adalah teh hitam dan $31 \%$ teh hijau. $^{12}$ Hal ini sesuai dengan penelitian yang dilakukan oleh Ernawati dkk mengatakan bahwa teh hijau mengandung katekin, yang di mana katekin mempunyai efek hipokolesterolemik dikarenakan katekin dapat menekan absorpsi kolesterol di dalam usus, maka pemberian ekstrak teh hijau yang diberikan kepada orang yang mengalami overweight dan obesitas dapat menurunkan total lemak tubuh (TLT) secara signifikan. ${ }^{4}$

Teh hijau memiliki banyak komponen seperti katekin, kafein, theanine dan vitamin. ${ }^{13}$ Katekin hadir dari $15 \%$ hingga $20 \%$ berat dalam teh hijau. Katekin teh hijau memiliki efek hipokolesterolemia ${ }^{14}$ dan menekan penyerapan kolesterol usus. Selain itu, dilaporkan bahwa epigallocatechin gallate (EGCG), sejenis katekin, memiliki efek penghambatan pada asetil-KoA karboksilase yang penting untuk biosintesis asam lemak in vitro dan efek anti-obesitas pada dosis tinggi pada tikus. $^{15}$ Sesuai dengan penelitian yang dilakukan Frank dkk, yang menyatakan bahwa efek yang sangat menguntungkan dari teh hijau adalah katekinnya, khususnya epigallocatechin-3-gallate (EGCG). ${ }^{16}$

Telah ditunjukkan bahwa kafein menurunkan asupan makanan dan meningkatkan termogenesis dan bahwa efek termogenik mendorong penurunan berat badan. Selain itu, diklarifikasi bahwa termogenesis oleh kafein secara sinergis ditingkatkan dengan katekin dalam jaringan adiposa tikus. Theanine (Áglutamylethylamide) adalah asam amino utama yang khas untuk teh hijau dan memiliki efek fisiologis seperti aktivitas relaksasi, aktivasi metabolisme dopamin dan pelepasan di otak. Selain itu, dilaporkan bahwa theanine menekan eksitasi oleh kafein. ${ }^{17}$ Ini sejalan dengan penelitian soraya $\mathrm{dkk}$, yang mengatakan bahwa terdapat tiga komponen utama the hijau, yaitu epigallocatechin gallate (EGCG) Caffein, dan $L$ - theanine yang menjadi rahasia utama teh hijau dalam menurunkan berat badan. ${ }^{18}$

\section{KESIMPULAN}

Terdapat pengaruh pemberian estrak daun teh hijau (Camellia sinensis) terhadap penurunan berat badan pada tikus putih (Rattus novergicus L.) jantan galur wistar sebelum diberikan ekstrak daun teh hijau (Camellia Sinensis) dan sesudah diberikan ekstrak daun teh hijau (Camellia Sinensis).

Kandungan dalam teh hijau yang diperoleh dari penelitian ini adalah flavonoid, tanin dan saponin. Tetapi kandungan yang paling berpengaruh terhadap penurunan berat badan yaitu Epigallocatechin-3-gallate, L-theanine, dan caffein tidak didapatkan karena keterbatasan alat.

\section{REFERENSI}

1. WHO. Obesity and Overweight; 2016.

2. Kemenkes RI. Hasil Utama Kesehatan Daerah (RISKESDAS).; 2018.

3. Dewi K. Pengaruh Ekstrak Teh Hijau Terhadap Penurunan Berat Badan , Kadar Trigliserida dan Kolesterol Total pada Tikus Jantan Galur Wistar. Maranatha J Med Heal. 2008;7(2):1-11.

4. Hardani E, Lestariana W. Efek Pemberian Ekstrak Teh Hijau ( Camellia sinesis ( $\mathrm{L}$ ) $\mathrm{O}$. Kuntze ) var . Assamica Terhadap Total Lemak Tubuh dan Profil Lipid Wanita Dewasa Overweight dan Obesitas. J Gizi Klin Indones. 2014;10(4):209-217.

5. Simanjuntak K. Peran Antioksidan Flavonoid Dalam Meningkatkan Kesehatan. Bina Widya. 
2012;23(3):135-140.

6. Martono B, Setiyono RT. Skrining Fitokimia Enam Genotipe Teh. J Tanam Ind dan Penyegar. 2014;1(2):63-68.

7. Xin Z, Man Z, TangHo-Chi, et al. Metagenomics Analysis of Gut Microbiota Modulatory Effect of Green Tea Polyphenols by High Fat Diet-induced Obesity Mice Model. J Funct Foods. 2018;46:268-277.

8. Nuryani, Nuryani, et al. Efektivitas Ekstrak Etanol Daun Afrika (Vernonia Amygdalina Del.) sebagai Obat Antikolesterol pada Tikus Jantan Galur Wistar yang Diinduksi Kuning Telur. Buletin Farmatera, 2018, 3.3: 174-180

9. Agristika A. Komplikasi Obesitas Pada Anak dan Upaya Penanganannya. Med J Lampung Univ. 2015;4(7):81-84.

10. Singh DP, Singh J, Boparai RK, et al. Isomalto-oligosaccharides, a prebiotic, functionally augment green tea effects against high fat diet-induced metabolic alterations via preventing gut dysbacteriosis in mice. Pharmacol Res. 2017; 123:103-113.

11. $M a ~ J Q$, Jin JQ, Yao $M Z$, et al. Quantitative Trait Loci Mapping for Theobromine and Caffeine Contents in Tea Plant (Camellia sinensis). J Agric Food Chem. 2018;66(50):13321-13327.

12. Cunha CA, Lira FS, Rosa Neto JC, et al. Green tea extract supplementation induces the lipolytic pathway, attenuates obesity, and reduces low-grade inflammation in mice fed a high-fat diet. Mediators Inflamm. 2012;2013:1-9.

13. Nur AA. Taklukkan Penyakit Dengan Teh Hijau. 1st ed. (Lukito A, ed.). Jakarta: PT Agro Media Pustaka; 2006.

14. Mawarti $\mathrm{H}$, Ratnawati R. Penghambatan Peningkatan Kadar Kolesterol Pada Diet Tinggi Lemak Oleh Epigallocatechin Gallate (EGCG) Teh Hijau Klon Gmb4. J Univ Pesantren Tinggi Darul 'Ulum.
2012;1(2).

15. Adelina R. Mekanisme Katekin Sebagai Obat Antidislipidemia (Uji In Silico). Bul Penelit Kesehat. 2018;46(3):147-154.

16. Thielecke F, Boschmann M. The Potential Role of Green Tea Catechins in the Prevention of the Metabolic Syndrome. Phytochemistry. 2009;70(1):11-24.

17. Guodong Z, Kazutoshi S, Tsutomu $\mathrm{O}$, Raj JL, Itaro O. Anti-obesity Effects of Three Major Components of green tea, catechins, caffeine and theanine, in mice. In Vivo (Brooklyn). 2004;18(1):55-62.

18. Rahmanisa S, Wulandari R. Pengaruh Ekstrak Teh Hijau terhadap Penurunan Berat Badan pada Remaja. Med J Lampung Univ. 2016;5(2):106-111. 